\title{
Dynamic Thermal Study of a Building Insulated with Local Biosource Materials and Analysis of Consumption
}

\author{
Guy Clarence Semassou ${ }^{1}$, Jean-Louis Comlan Fannou ${ }^{1,2}$, Edmond Claude Vodounnou', \\ Mèdéhou Elogni Segbotangni ${ }^{1}$, Kouamy Victorin Chegnimonhan ${ }^{3,4}$ \\ ${ }^{1}$ Mechanical and Energy Engineering Department, Polytechnic School of Abomey-Calavi, Abomey-Calavi, Benin \\ ${ }^{2}$ National Higher School of Energy and Processes Engineering, National University of Sciences, Technology, Engineering and Mathematics, \\ Abomey, Benin \\ ${ }^{3}$ National Center of Scientifics Researches, University of Nantes, Nantes, France \\ ${ }^{4}$ Benin National Center of Research and Innovation, University of Abomey-Calavi, Abomey-Calavi, Benin
}

Email address:

clarence.semassou@gmail.com (G. C. Semassou)

\section{To cite this article:}

Guy Clarence Semassou, Jean-Louis Comlan Fannou, Edmond Claude Vodounnou, Mèdéhou Elogni Segbotangni, Kouamy Victorin Chegnimonhan. Dynamic Thermal Study of a Building Insulated with Local Biosource Materials and Analysis of Consumption. American Journal of Energy Engineering. Vol. 9, No. 2, 2021, pp. 48-59. doi: 10.11648/j.ajee.20210902.14

Received: May 13, 2021; Accepted: May 28, 2021; Published: June 7, 2021

\begin{abstract}
The quality of infrastructure, including buildings, is an indicator of a country's development status. However, it must be noted that these buildings entail high energy costs and also contribute to the global greenhouse effect. The building sector is therefore a crucial issue in terms of adapting to climate change because it is at the heart of a dual energy and environmental problem. To address this challenge, energy efficiency policies are increasingly being adopted worldwide, with the aim of improving the energy performance of buildings. In the present work, the thermo-physical properties of four types of materials, namely: "cement and roast fibre" composite, "cement and rice husk" composite, "agglomerate" and "cement and bar soil" composite, were exploited to implement thermal simulations under TRNSYS environment. The aim was to determine the thermal contributions of the walls built with these materials and those allowing a better comfort in the building by estimating and comparing the energy needs of the proposed variants with those of the reference building. The study showed that the walls made of "cement and rice husks" composite and "cement and roast tree fibres" composite allow to reduce respectively by $20 \%$ and $11 \%$, the cooling needs linked to air conditioning for the living room, and respectively by $32 \%$ and $27 \%$ for the bedroom, compared to the reference building made of agglomerate (with a thickness $\mathrm{e}=0.15 \mathrm{~m}$ ). For the walls made of "cement and earth bar", the cooling requirement increased by $31 \%$ for the living room and decreased by $5 \%$ for the bedroom, compared to the "chipboard" reference building. Furthermore, the TEWI evaluation showed that the "cement and rice husk" and "cement and roast fibre" composites have a lower environmental impact.
\end{abstract}

Keywords: Thermal Insulation, Roast Wood Fibres, Rice Husks, Chipboard, Bar Soil, Dynamic Thermal Simulation

\section{Introduction}

Awareness of the depletion of energy resources and global warming is leading governments to adopt new policies and strategies for sustainable development. Faced with a growing population in the coming decades and a development model that is energy-intensive, resource-consuming and polluting, it becomes important to review our consumption habits for sustainable socio-economic development. Among the fortyfive leading projects of the Beninese Government Action
Programme (GAP) to boost its socio-economic development, four are devoted to the energy sector and more specifically, one of them is devoted to "Controlling energy consumption" [1]. Indeed, energy is at the heart of all development issues. As such, from its production to its final consumption, via its transport, measures aimed at improving the performance of this chain must be taken to contribute to the development of the key and vital sectors it impacts. The building sector is a major energy consumer. Indeed, between 1997 and 2010, final energy consumption in the building sector doubled to 
2794 million tonnes of oil equivalent (Mt eq.) [2]. This increase in consumption is a direct consequence of demographic and economic growth with a greater search for comfort. If the trend continues, overall energy demand in this sector is expected to increase by a further $30 \%$ between 2010 and 2035, equivalent to the energy demand of the buildings sector in China and the USA combined [3]. This evolutionary trend can also be observed in Benin. Indeed, from 1996 to 2010, final energy consumption in Benin has continued to increase in the residential sector, still leading the other sectors with an average growth rate of $5.3 \%$ over the period [4]. These statistics show that energy is a highly adopted input in the buildings sector in Benin and this upward trend will only increase in the coming years. As energy resources fluctuate, they must be used rationally to achieve greater efficiency. These efficiency measures require a better knowledge of certain data related to the energy performance of the building envelope, the energy intensity and the sources of energy losses. In a first reliable approach such matters can be checked by the use of numerical models and simulation tools, which are reasonable means, in terms of time and cost, to analyse and understand the behaviour of buildings and to improve their energy performance, both in the design and life cycle phases. The main use of simulation models is to subject them to a variety of conditions, observe the resulting results and deduce the behaviour of the real system under the same conditions. In the case of the present study, the TRNSYS software was chosen to simulate the heat transfers in the reference building. This choice is based on the validity of the TRNSYS software. The work of Necib et al [5] has led, among other things, to the validation of the TRNSYS 16 software. Indeed, they compared the measured and simulated indoor temperature of the teachers' room, the object of their study, located at the University Kasdi Merbah-Ouargla in Algeria. The simulated and measured values of the indoor temperature of the teachers' room revealed a perfect match at $8 \mathrm{am}, 12 \mathrm{pm}$ and $5 \mathrm{pm}$. Apart from these points, the simulated temperature slightly exceeded the measured one, the maximum deviation was $0.961{ }^{\circ} \mathrm{C}$, i.e. a maximum relative difference of $3.4 \%$. Similarly, Nefissa Belkacem has shown in her thesis that the simulated temperature remains qualitatively faithful to the evolution of the experimental values in the case of a pilot house in Algiers [6]. Thomas Marchal represented a passive house as closely as possible, by modelling the different heat flows present and simulating the temperatures of each of the rooms in the house over the year [7]. He also modelled the different thermal equipment attached to it: Canadian well, solar thermal panels, photovoltaic panels and storage tank. From the comparisons made between the results recovered by simulation and those obtained experimentally from the collectors installed in the passive house, the simulation is faithful to reality. Moreover, among the thermal contributions of a building, those passing through the envelope, in this case the walls, have an important proportion. Indeed, M. Jedidi et al. [8] have shown that the building envelope has a significant impact on energy consumption. Similarly, the quality of the materials used in the construction of the envelope has an effect on thermal comfort. O. Godonou [9], has shown experimentally that "cement+rice husks" and "cement + n fibres" composites have good thermal insulation properties. It is in this context that the idea of the present study arises. The objective is to explore the reduction of energy consumption in the building sector, and more specifically in residential buildings constructed with some local bio-based materials of Benin within the TRNSYS software environment. This paper firstly outlines the research methodology adopted and the hardware used. A presentation of the TRNSYS simulation software is given, as well as an overview of some insulating materials. The case study is a residential building located in the commune of Abomey-Calavi. The modelling depends on the choice of building materials for the envelope, thermal gains, climatic data etc. It will allow to present the simulation as an alternative for the estimation of the energy consumption of the buildings and to valorise the local building materials.

\section{Materials and Methods}

First, the thermal behaviour of a reference building made the reference configuration made of "breeze block and cement" was studied in order to determine the energy consumption and the cooling requirement. Then the thermal behaviour of the same building was studied, this time by replacing the chipboard walls with three types of composites: "cement+rice husks" composite, "cement+roast wood fibres" composite and "cement+bar soil" composite in order to determine which one allows the best energy saving in the case of air conditioning. To this end, thermal and dynamic simulations were carried out using TRNSYS 17 software.

\subsection{Materials}

\section{Presentation of the reference building}

The studies are carried out on a residential building located in the commune of Abomey-Calavi, a commune in the south of Benin. The building is located in the "Cité la Victoire" district. Its geographical coordinates are Latitude: $6^{\circ} 24 ' \mathrm{~N}$ and Longitude: $2^{\circ} 20^{\prime} \mathrm{E}$. Meteorological data for the city of Abomey-Calavi, a city close to Cotonou, are unavailable on TRNSYS. In a similar case, Henri Hounkpatin et al. recommend using that of Ikeja given the proximity of this city to Cotonou [10]. The building is a residence built on an area of $80 \mathrm{~m}^{2}$. The roof is made of concrete and the main entrance to the building is located on the eastern side. The wall is built with $15 \mathrm{~cm}$ hollow blocks (breeze block), and is covered on the outside and inside with an estimated $2 \mathrm{~cm}$ thick cement plaster (Figure 1).

Input data and mathematical model for cooling demand estimation

A residential building is modelled in this study. The dimensions of the reference building as well as its geometric shape are modelled using Google Sketchup drawing software (Figure 1). As shown in Figure 2, the characteristics of the house (orientation, thermal characteristics of the components, etc.), air infiltration and internal heat gains are the main 
inputs of type 56 according to TRNSYS.

a

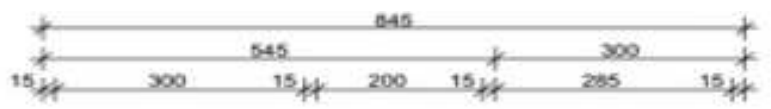

감

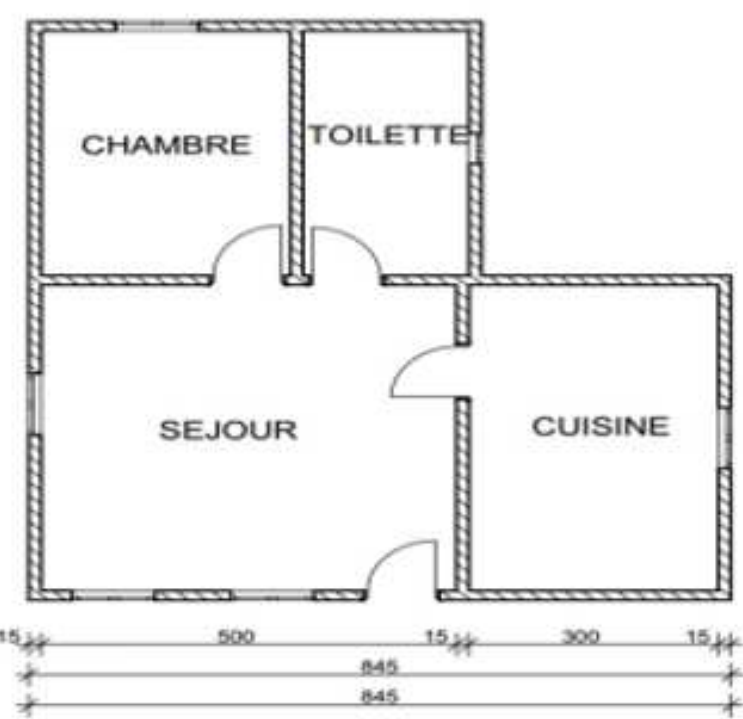

b

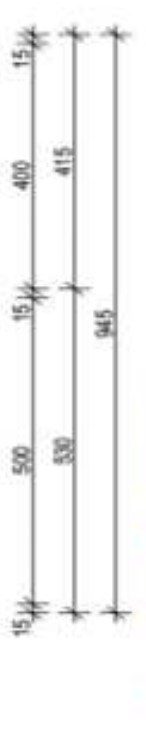

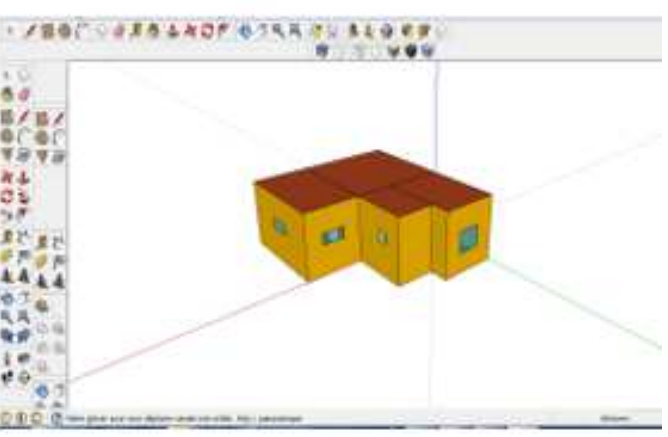

Figure 1. Building plan: (a) in 2-D. (b) in 3D. (c) with Google Sketchup.

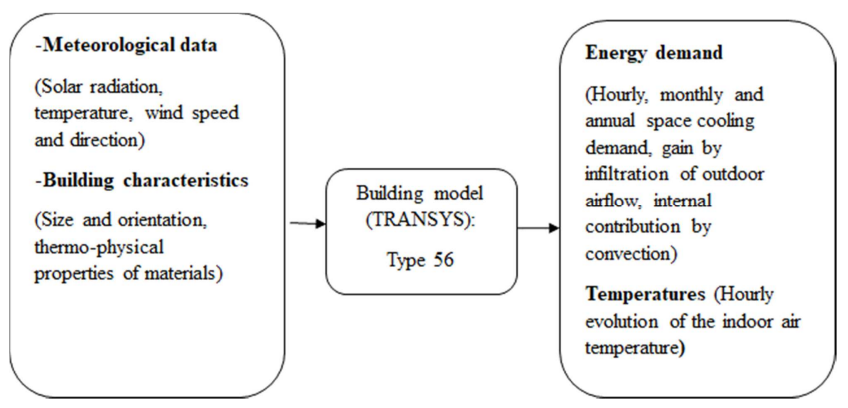

Figure 2. Inputs and outputs of the building model [11].

The convective heat flow in the building is governed by the following equations [12]:

$$
\dot{\mathrm{Q}}_{\mathrm{T}}=\dot{\mathrm{Q}}_{\mathrm{surf}}+\dot{\mathrm{Q}}_{\mathrm{inf}}+\dot{\mathrm{Q}}_{\mathrm{vent}}+\dot{\mathrm{Q}}_{\mathrm{gain}}+\dot{\mathrm{Q}}_{\mathrm{cplg}}
$$

With:

$$
\begin{gathered}
\dot{\mathrm{Q}}_{\text {inf }}=\rho_{\mathrm{a}} \dot{\mathrm{V}} \mathrm{c}_{\mathrm{a}}\left(\mathrm{T}_{\text {ext }}-\mathrm{T}_{\mathrm{i}}\right) \\
\dot{\mathrm{Q}}_{\text {vent }}=\rho_{\mathrm{a}} \dot{\mathrm{V}} \mathrm{c}_{\mathrm{a}}\left(\mathrm{T}_{\text {vent, } \mathrm{I}}-\mathrm{T}_{\mathrm{i}}\right) \\
\dot{\mathrm{Q}}_{\text {surf }}=\mathrm{h}_{\mathrm{c}} \mathrm{S}\left(\mathrm{T}_{\mathrm{s}, \mathrm{i}}-\mathrm{T}_{\mathrm{i}}\right) \\
\dot{\mathrm{Q}}_{\text {cplg }}=\rho_{\mathrm{a}} \dot{\mathrm{V}}_{\mathrm{a}}\left(\mathrm{T}_{\text {zone }, \mathrm{i}}-\mathrm{T}_{\mathrm{i}}\right)
\end{gathered}
$$

In this part of the study, the ventilation is natural. Thus, for a first approach, it can be considered that the energy contributions by ventilation are negligible, given the low flow rates induced.

\subsection{Method}

Two methods have traditionally been applied to model energy consumption in the residential sector [13]:
1. The inverse method refers to statistics and is based on historical data of a large building stock. It allows to retrieve the characteristics of the stock from the general consumption data, in a similar way to a model calibration but on a stock scale. Factors considered include envelope insulation levels, presence of daylighting, power of installed equipment, heating temperature set point, presence of mechanical ventilation, infiltration rate and heating system efficiency [14].

2. The prospective method focuses on an in-depth analysis of the building envelope and its components.

Energy foresight models are a valuable ally in decision support. By taking a long-term view and integrating all economic and political factors, they allow a coherent picture of energy systems to be drawn. Countless energy forecasting models can be used. Each model is characterised by the issue to be addressed. Foresight modelling is not intended to provide certainty about the future. It is in no way a forecast. Indeed, it only allows us to anticipate a framework of probable evolution based on plausible scenarios [15].

This article deals with the thermal and dynamic study of a building, in this case the envelope, by means of energy simulation. The second modelling method has therefore been chosen to identify opportunities for technological improvements at the design stage of the building using local bio-based materials.

This will involve parameterising the TRNSYS software with the characteristic data of the reference building using the TRNBuild software (Type 56).

The assumptions made for a first calculation approach are as follows:

A calculation step of one hour is set for each iteration due to the small variation in time. 
March, the hottest month of the year, is chosen for the simulation period.

As far as the internal inputs are concerned, the hypotheses formulated can be summarised as follows:

The people dwelling in the house: 2

A set of electronic equipment of $230 \mathrm{~W}$ (a $30 \mathrm{~W}$ laptop and a $200 \mathrm{~W}$ television set)

A set of lighting of $5 \mathrm{~W} / \mathrm{m}^{2}$

The temperature and initial humidity are taken as $28^{\circ} \mathrm{C}$ and $60 \%$ respectively (these values belong to the comfort zone of Cotonou, near Abomey-Calavi).

The air infiltration coefficient is 0.6 volume/hour. (Normalized value given on TRNSYS).

We then simulate the evolution of the air temperature inside the reference building as well as the energy needs for air conditioning. Finally, the evolution of the indoor air temperature and the energy requirements for air conditioning are studied by replacing the agglomerate constituting the envelope of the reference building with three other composites: "cement+ rice husks" composite; "cement+ roast wood fibres" composite and "cement+ bar soil" composite.

Types of building materials

The building envelope acts as a thermal barrier between the indoor and outdoor environments. It serves as a receptacle (or storage) of heat in the building and as a distributor of heat to the indoor and outdoor air [16, 17]. In a first approach, the thermal performances of three types of materials in addition to our base case are tested: composite cement + roast wood fibre; composite cement + rice husk; composite cement+ bar soil. Indeed, from the study of Godonou [9], it appeared that the composite cement and rice husks and the composite cement and roast tree fibres present the best thermal retention capacities and allow to improve the thermal comfort in our buildings.

Then, a detailed study and analysis of the thermal behaviour of the envelope; specifically of the walls with different compositions are proposed in order to identify those that allow the greatest energy saving in the case of air conditioning.

\section{Environmental impact}

Environmental impact refers to all qualitative, quantitative and functional changes in the environment (negative or positive) caused by a project, a process, an organisation(s) and a product(s), over its life cycle. It is characterised by the TEWI (Total Equivalent Warning Impact) in Refrigeration and Air Conditioning.

The TEWI is calculated according to the formula:

$$
\begin{gathered}
\text { TEWI = Direct Global Warming } \\
+ \text { Indirect Global Warming }
\end{gathered}
$$

$$
\begin{gathered}
T E W I=\left(G W P_{100} * L * n\right)+\left[G W P_{100} *\left(1-\alpha_{\text {recovery }}\right)\right]+ \\
\left(\mathrm{n} * E_{a} * \beta\right)
\end{gathered}
$$

Further assumptions:

Refrigerant: R410A, GWP ${ }_{100}=1975, \mathrm{~L}=0.075, \mathrm{n}=20$ years, $\alpha_{\text {recovery }}=0.75, \beta=0.456$;

$\mathrm{COP}=3$, annual working time of the air conditioning: 2000 hrs.

Ea: Annual energy consumption $[\mathrm{kWh} /$ year $]=($ Cooling capacity *2000)/COP

\section{Results and Analyses}

This section is dedicated to the analysis and interpretation of data from successive simulations carried out in TRNSYS with different wall compositions, namely: "chipboard", "cement+root fibre" composite, "cement+rice husk" composite and "cement+bar soil" composite.

These analyses allowed to produce graphs dealing with the variation of the indoor air temperature and the cooling energy requirement.

Temperature d'air extérieur $\left({ }^{\circ} \mathrm{C}\right)$
- Température

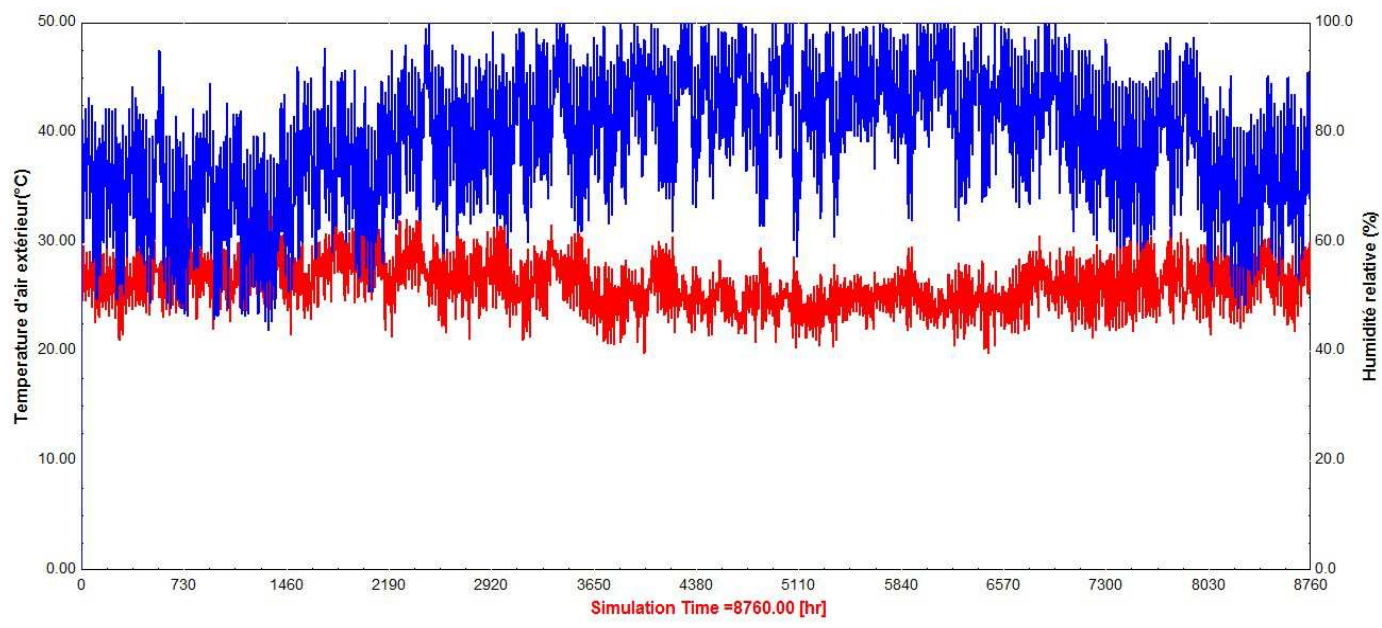

Figure 3. Annual variation of outdoor air temperature and relative humidity (Source: TRNSYS).

Figure 3 shows the annual variation of air temperature and relative humidity. It can be seen that temperatures between 
25 and $34{ }^{\circ} \mathrm{C}$ are the most frequent in this region. The hottest months are characterised by proportions of temperatures above $30{ }^{\circ} \mathrm{C}$. The highest values are reached in January, March and October, and the lowest ones in December, July and August.

The lowest values of relative humidity are between November and March, and then mid-July and midSeptember. This occurs in the dry season. The highest values are found between April and July and mid-September to October, with a peak in August during the rainy seasons when they are above $90 \%$. But overall the humidity remains above $50 \%$ throughout the year.

Figure 4 shows the variation of global radiation, normal direct radiation and diffuse radiation over the year.

The horizontal global insolation varies between 0 and 3053 $\mathrm{kJ} / \mathrm{h} \cdot \mathrm{m}^{2}\left(848 \mathrm{~W} / \mathrm{m}^{2}\right)$. It is higher than direct and diffuse irradiation. The global irradiation is in fact the sum of the diffuse and direct irradiations. The zero value of the three irradiations is observed simultaneously at night due to the absence of the sun. The individual irradiances have low values at times due to the reduction in solar radiation intensity caused by the presence of clouds. Overall the peak values of the different irradiances are high due to the tropical climate.

Figure 5 shows the annual variation of the outdoor air temperature and the horizontal global irradiance.

The results presented in this figure show that the increase in ambient temperature is due to the increase in solar radiation. There is therefore a correlation between the increase in ambient temperature and the increase in solar radiation. The maximum solar radiation is $833 \mathrm{~W} / \mathrm{m}^{2}$ and the minimum is $138 \mathrm{~W} / \mathrm{m}^{2}$. The highest temperature values of $31^{\circ} \mathrm{C}$ and $34^{\circ} \mathrm{C}$ can also be observed at these points.

Figure 6 provides information about the composition of the envelope of the building and Table 1 gives details on the thermophysical properties of materials.

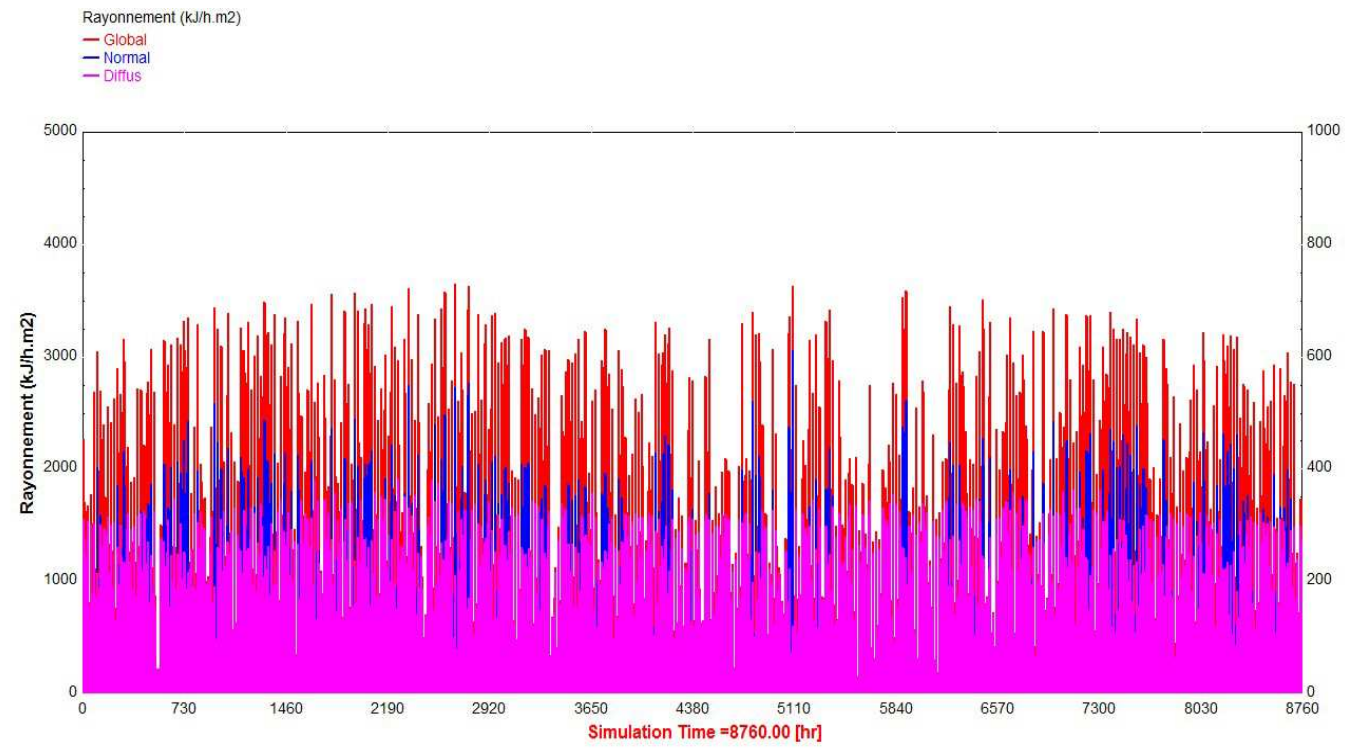

Figure 4. Annual global, normal and diffuse sun irradiation (Source: TRNSYS).

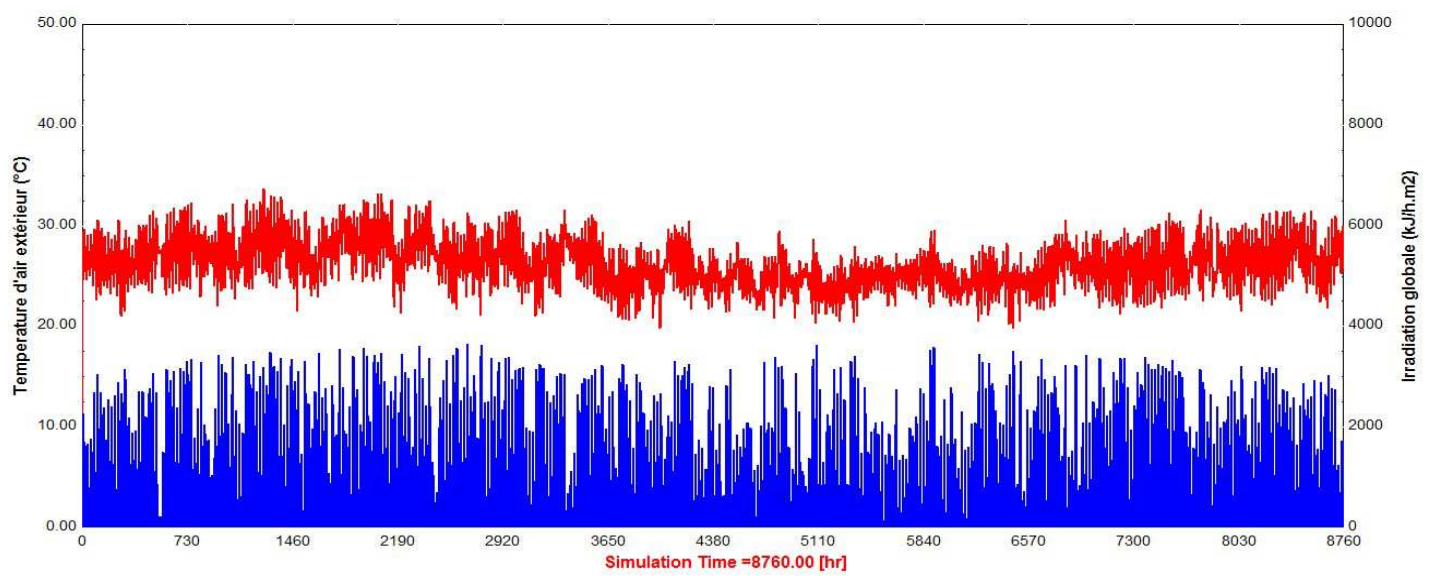

Figure 5. Annual variation of air temperature and global irradiation (Source: TRNSYS). 
Table 1. Thermophysical properties of materials [18].

\begin{tabular}{lllll}
\hline Building envelope & $\begin{array}{l}\text { Composition of the } \\
\text { envelope }\end{array}$ & $\begin{array}{l}\text { Thickness } \\
(\mathbf{m})\end{array}$ & $\begin{array}{l}\text { Thermal Conductivity } \\
(\mathbf{W} / \mathbf{m} . \mathbf{K})\end{array}$ & $\begin{array}{l}\text { Density } \\
\left(\mathbf{k g} / \mathbf{m}^{\mathbf{3}}\right)\end{array}$ \\
\hline \multirow{3}{*}{ Wall } & Interior cement plaster & 0.02 & 1.15 & 1700 \\
& Hollow brick & 0.15 & 0.833 & 1000 \\
& Exterior cement plaster & 0.02 & 1.15 & 1000 \\
Exterior cement plaster & Exterior cement plaster & 0.02 & 1.15 & 1000 \\
& Concrete-Hourdis & 0.2 & 1.4 & 1000 \\
Floor & Smooth cement plaster & 0.02 & 1.15 & 1001 \\
& Concrete & 0.1 & 1.4 & 1000 \\
\hline
\end{tabular}

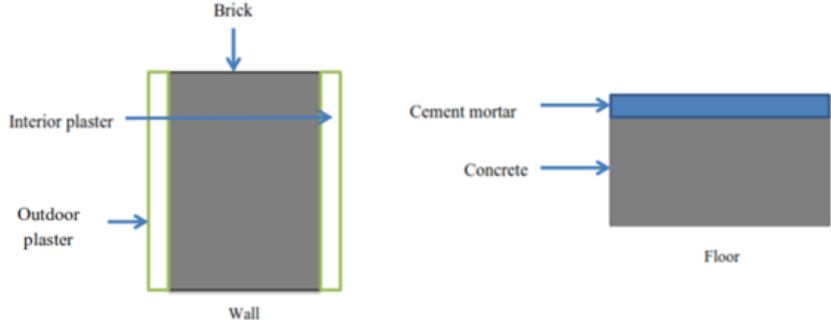

Figure 6. Wall and floor composition.

The different option of the wall studied (table 2) and some pictures of the raw materials are displayed on Figure 7.

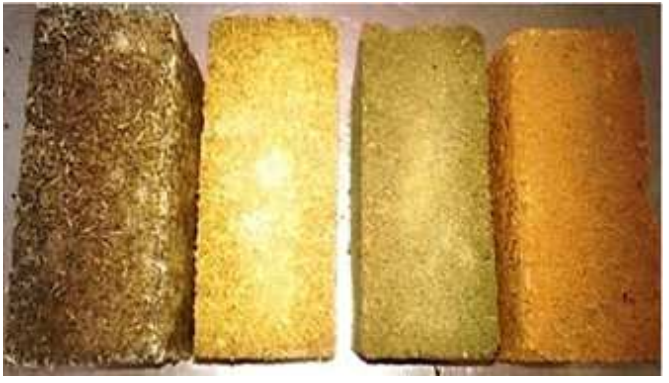

Figure 7. From left to right: Cement+roast wood fibre composite; Composite of cement+rice husks; Agglomerate; Composite of cement+bar soil (O. Godonou, 2015).

Table 2. The different options studied.

\begin{tabular}{lll}
\hline & Options & Description \\
\hline \multirow{3}{*}{ Envelopes } & 1 & Cement + roast fibre composite \\
& 2 & Cement + rice husks composite \\
& 3 & Breeze block + cement (reference) \\
\hline
\end{tabular}

Tables 3 and 4 show the composition of the material samples used and the thermo physical characteristics of the different wall configurations respectively.

Table 3. Composition of samples (O. Godonou, 2015).

\begin{tabular}{|c|c|c|c|c|}
\hline $\begin{array}{ll}\text { Materials } & \text { Composition } \\
\end{array}$ & Mass of cement (g) & Mass of water (g) & Mass of aggregates (g) & Total mass (g) \\
\hline Cement and roast fibre Composite & 544 & 191 & 595 & 1329 \\
\hline Cement and rice husks Composite & 544 & 191 & 477 & 1211 \\
\hline Cement and bar soil Composite & 544 & 191 & 1921 & 2655 \\
\hline
\end{tabular}

Table 4. Thermophysical characteristics of the configurations $(e=0.15 \mathrm{~m})$.

\begin{tabular}{llll}
\hline Wall & $\begin{array}{l}\text { Thickness } \\
(\mathbf{m})\end{array}$ & $\begin{array}{l}\text { Thermal Conductivity } \\
(\mathbf{W} / \mathbf{m} . \mathbf{K})\end{array}$ & $\begin{array}{l}\text { Specific heat } \\
(\mathbf{J} / \mathbf{k g . K})\end{array}$ \\
\hline Cement and roast fibre Composite & 0.15 & 0.538 & 4638.51 \\
Cement and rice husks Composite & 0.15 & 0.475 & 5157.75 \\
Breezeblock and cement (reference wall) & 0.15 & 1.129 & 1760.87 \\
Cement and bar soil Composite & 0.15 & 0.883 & 556.78 \\
\hline
\end{tabular}

\subsection{Evolution of the Indoor Air Temperature}

In the following section, the evolution of the indoor air temperature that would prevail in the reference building is presented, as well as those of the buildings obtained from composite walls "cement + roast fibre", composite "cement + rice husks" and composite "cement + bar soil". The results show that for a thickness of $0.15 \mathrm{~m}$ and for identical simulation steps; the building with a wall envelope made of "cement + rice husks" gives the lowest values of indoor temperature. In contrast, the envelope with the reference wall made of breeze block and cement gives the highest values. The composites based on bar soil and roast wood give intermediate values.

These results are in agreement with those obtained experimentally by $\mathrm{O}$. Godonou [9], who stated that the "cement+rice husks" and "cement+roastwood fibres" composites have the best thermal insulation.

The following figures 8 to 11 show the evolution profile of 
the indoor air temperature in the studied building, according to the different composite walls.
As a critical simulation period, March was considered the hottest month of the year in Benin.

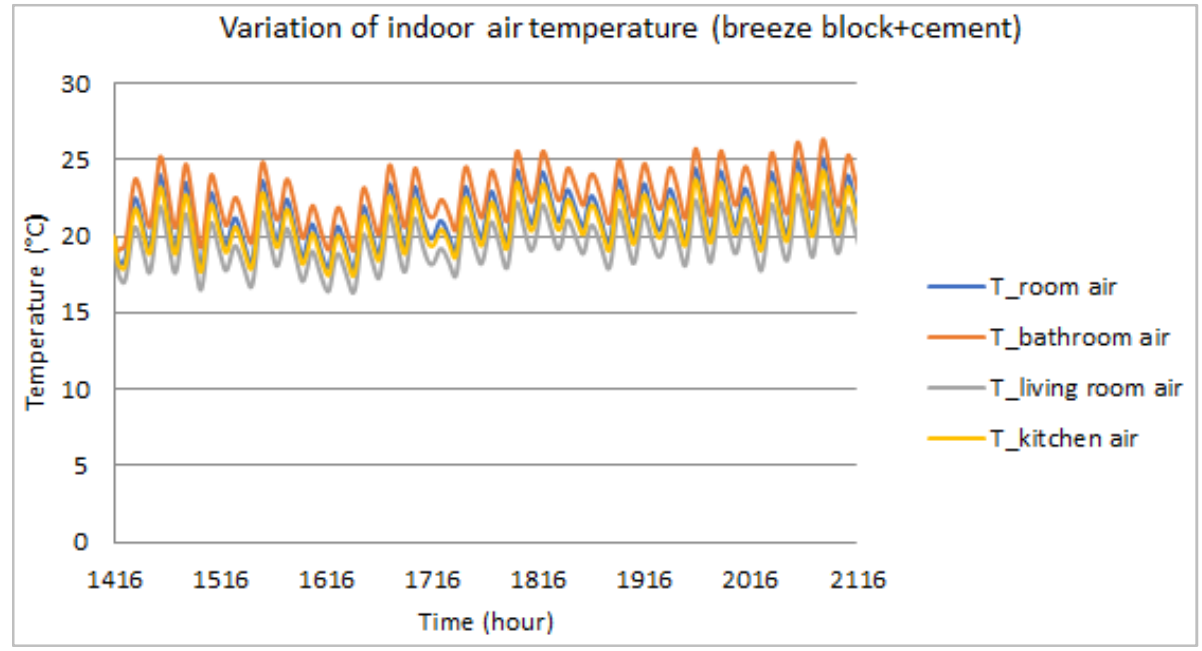

Figure 8. Variation of indoor air temperature (breeze block+cement).

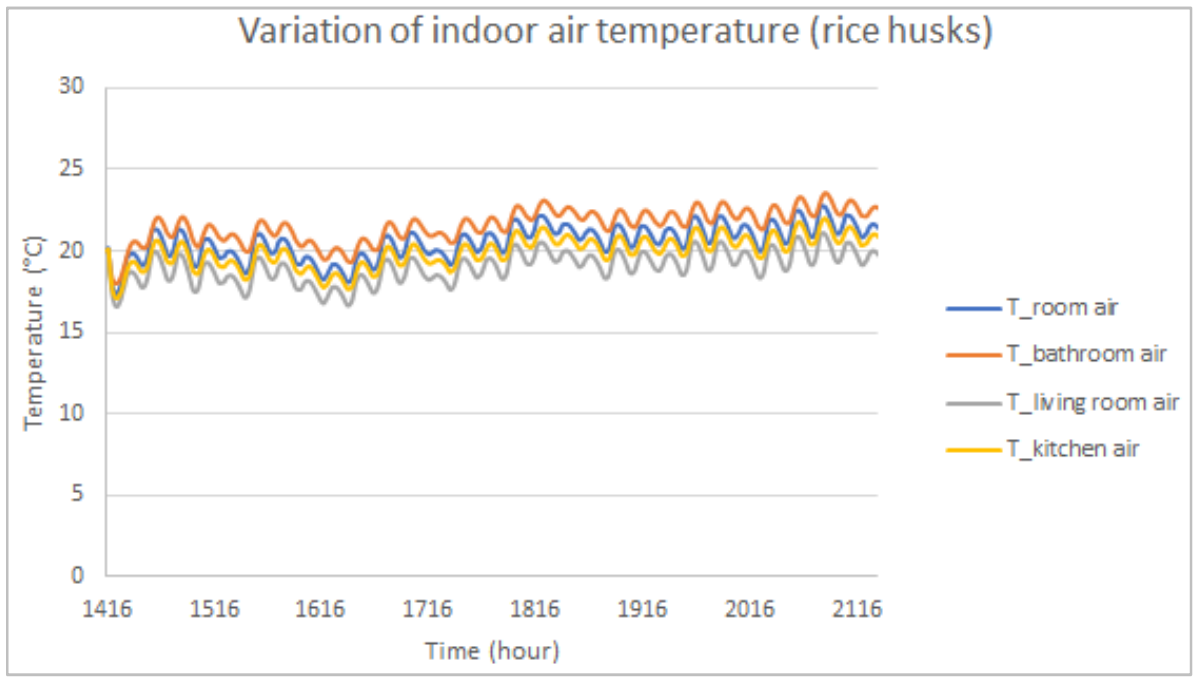

Figure 9. Variation of indoor air temperature (Rice husks).

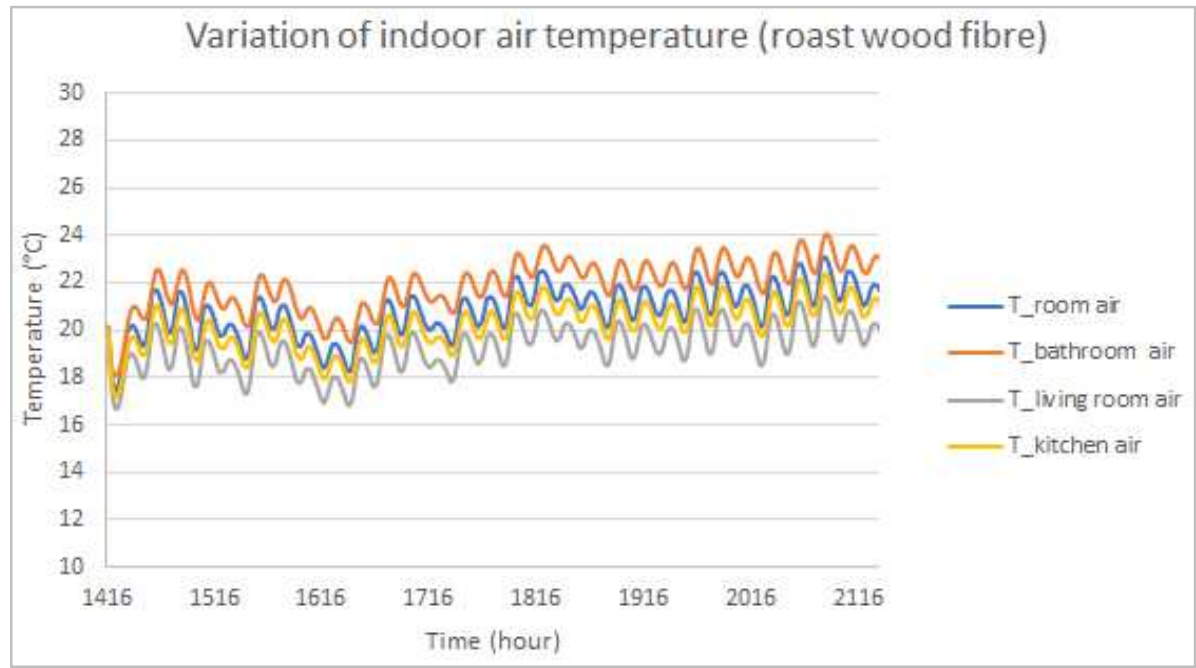

Figure 10. Variation of indoor air temperature (roast wood fibre). 


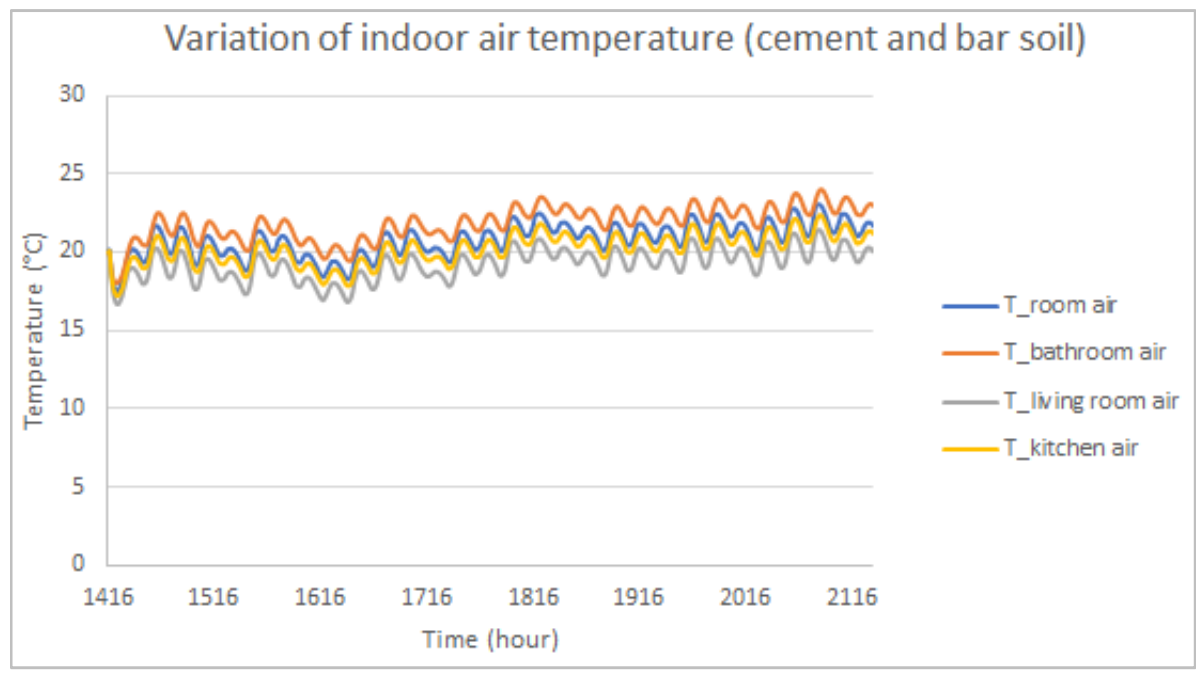

Figure 11. Variation of indoor air temperature (Cement and bar soil).

Table 5 displays the extreme values of the temperatures of the different parts of the building in terms of the wall compositions.

Table 5. Extreme values of part temperatures according to composites.

\begin{tabular}{|c|c|c|c|c|c|c|c|c|}
\hline \multirow[b]{2}{*}{ Wall types } & \multicolumn{2}{|l|}{ Room } & \multicolumn{2}{|l|}{ Bathroom } & \multicolumn{2}{|c|}{ Living room } & \multicolumn{2}{|l|}{ Kitchen } \\
\hline & $\mathbf{T}_{\max }\left({ }^{\circ} \mathrm{C}\right)$ & $\mathbf{T}_{\min }\left({ }^{\circ} \mathrm{C}\right)$ & $\mathbf{T}_{\max }\left({ }^{\circ} \mathrm{C}\right)$ & $\mathbf{T}_{\min }\left({ }^{\circ} \mathrm{C}\right)$ & $\mathrm{T}_{\max }\left({ }^{\circ} \mathrm{C}\right)$ & $\mathbf{T}_{\min }\left({ }^{\circ} \mathrm{C}\right)$ & $\mathbf{T}_{\max }\left({ }^{\circ} \mathbf{C}\right)$ & $\mathbf{T}_{\min }\left({ }^{\circ} \mathrm{C}\right)$ \\
\hline Cement+rice husks & 23 & 17 & 24 & 18 & 21 & 17 & 22 & 17 \\
\hline Cement+roastwood fibres & 23 & 17 & 24 & 18 & 21 & 17 & 22 & 17 \\
\hline Cement+bar soil & 23 & 17 & 24 & 18 & 21 & 17 & 22 & 17 \\
\hline
\end{tabular}

From the analysis of these data, it appears that the temperature values oscillate between $17^{\circ} \mathrm{C}$ and $23^{\circ} \mathrm{C}$, for the bedroom; $18^{\circ} \mathrm{C}$ and $23^{\circ} \mathrm{C}$, for the toilet; $17^{\circ} \mathrm{C}$ and $21^{\circ} \mathrm{C}$, for the living room and $17^{\circ} \mathrm{C}$ and $22^{\circ} \mathrm{C}$, for the kitchen, regardless of the composite considered. We deduce that the difference obtained from one room to another is explained by the difference in surface area occupied by each of these rooms, because the larger the surface area of the room, the better the dissipation of heat, which generates a decrease in the temperature of the indoor air. It is concluded that this difference is related to the inertia of the building envelope and to the energy intensity, which is the ratio between the amount of energy consumed by a sector and a variable representative of that sector (inhabitants, workers, number or surface of dwellings or offices, added value, etc.).

\subsection{Evolution of the Cooling Requirement}

Let $\mathrm{MbRr}$ and $\mathrm{MbRa}$ be the maximum cooling requirement of the reference building and the other configurations respectively.

The reduction of the cooling requirement is obtained by the following formula:

$$
\text { Reduction }=\frac{M b R r-M b R a}{M b R r}
$$

The maximum cooling requirement is the largest value in the data set provided by the simulation software for estimating the cooling requirement of a given configuration. Figures 12, 13, 14 and 15 show the evolution of the cooling energy requirement for the living room and the room, according to the different composites. The maximum values of the cooling requirement are given in Tables 6 and 7 .

Table 6. Reduction of the cooling requirement (Living).

\begin{tabular}{lll}
\hline Wall types & Maximum cooling requirement (Watt) & Reduced cooling requirements (\%) \\
\hline Breezeblock and cement (reference wall) & 2884 & 00 \\
Cement + rice husks & 2314 & 19.76 \\
Cement + roast wood fibre & 2570 & 10.88 \\
Cement + bar soil & 3789 & -31.38 \\
\hline
\end{tabular}

Table 7. Reduction of the cooling requirement (Room).

\begin{tabular}{lll}
\hline Wall types & Maximum cooling requirement (Watt) & Reduced cooling requirements (\%) \\
\hline Breezeblock and cement (reference wall) & 3703 & 00 \\
Cement + rice husks & 2538 & 3.46 \\
Cement + roast wood fibre & 2711 & 26.78 \\
Cement + bar soil & 3536 & 4.50 \\
\hline
\end{tabular}



Biosource Materials and Analysis of Consumption

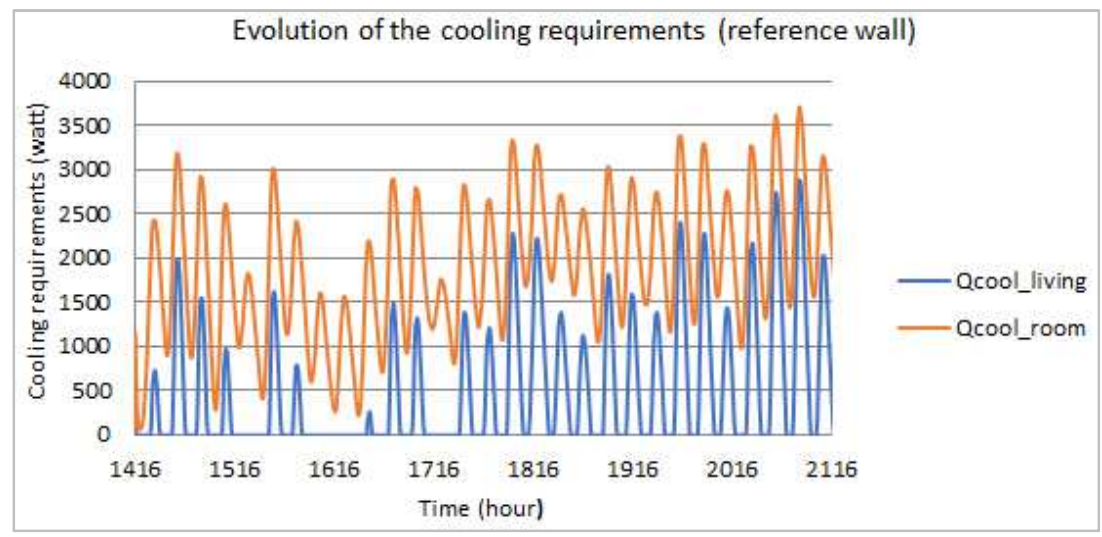

Figurer 12. Evolution of the cooling requirements (reference wall).

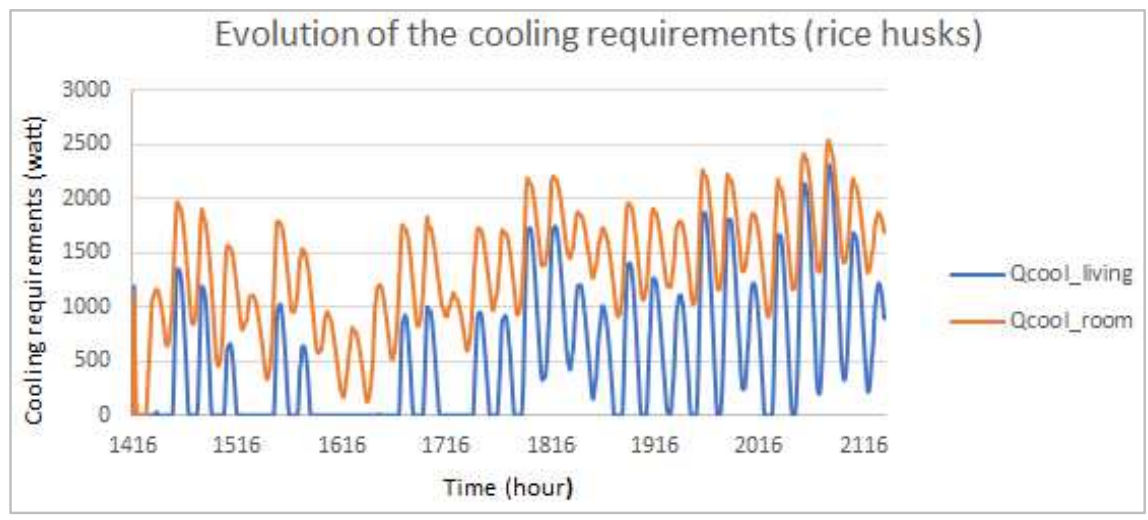

Figure 13. Evolution of the cooling requirements (rice husks).

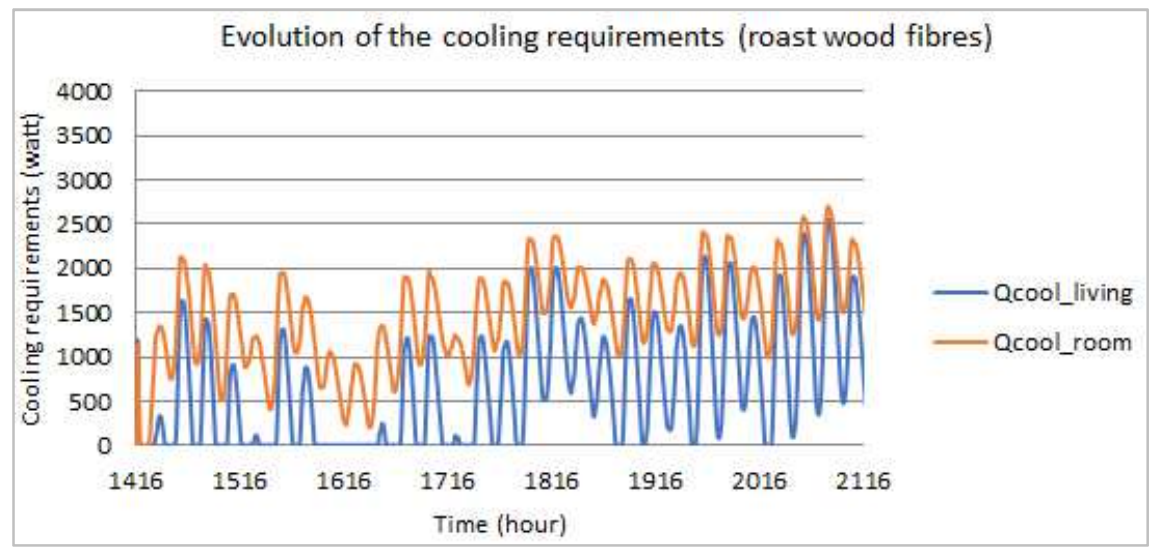

Figure 14. Evolution of the cooling requirements (roast wood fibres).

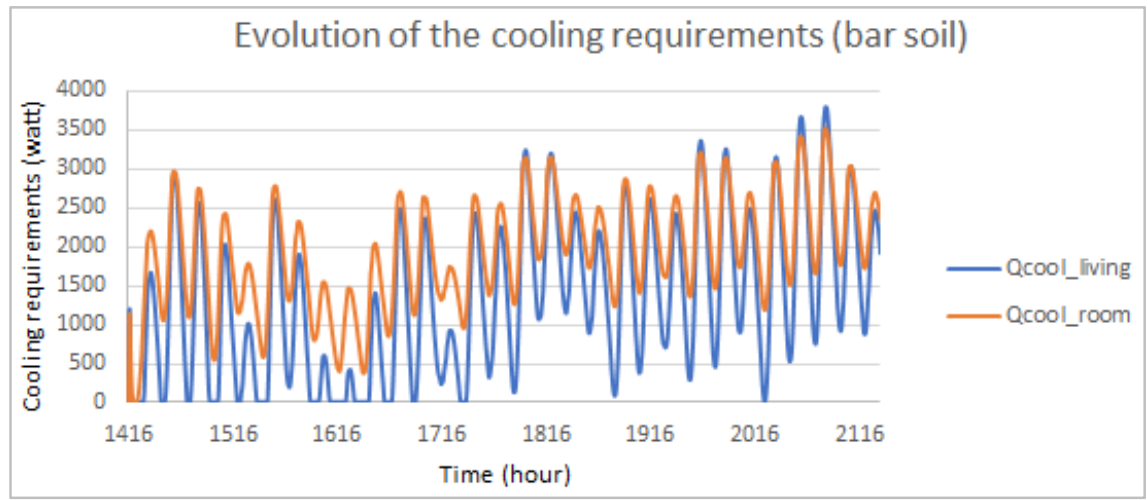

Figure 15. Evolution of the cooling requirements (bar soil). 
From the analysis of the results, it appears that the "cement + rice husks" and "cement + roast tree fibres" composites allow the best energy savings and thermal comfort. Indeed, the study showed that the walls built with the "cement + rice husks" composite and the "cement + roast wood fibres" composite allow a reduction of $20 \%$ and $11 \%$ respectively in the cooling needs linked to air conditioning for the living room, and $32 \%$ and $27 \%$ respectively for the bedroom, compared to the reference building made of chipboard. These two configurations therefore result in subsequent energy savings for air conditioning.

These results agree with those obtained by K. DOKO who states that cementitious composites reinforced with plant biomass, namely roast wood fibres and rice husks, have very good mechanical and thermal characteristics [19]. A comparative study of these two formulated materials revealed that concrete made from roast wood fibres is better in terms of mechanical performance. On the other hand, in conditions where thermal properties are more desirable, rice husks concrete is more recommended.

In the interests of energy efficiency, these types of materials are therefore to be preferred.

Moreover, in their study on Improving indoor environmental conditions in the northern region of Benin specifically for these case of residential buildings in Kandi, G. CHAFFA, C. AWANTO, L. A. FAGBEMI et al. analysed the thermal responses of the building envelope, as well as the resulting interior ambient conditions for walls made from conventional materials of different thicknesses such as hollow concrete block walls $(12 \mathrm{~cm})$, solid brick walls $(18 \mathrm{~cm})$ and those in earthen concrete $(25$ to $30 \mathrm{~cm})$ [20].
After simulations, they obtained results which show that in dry tropical regions, earthen concrete buildings well protected from sunlight promote better ambient conditions both day and night. In addition, the building envelope is involved in determining the amount of energy required to maintain thermal comfort.

Indeed, in hot countries like Benin, the design of a good building envelope reduces the amount of energy used for air conditioning.

This supports the results of this study.

Also, G. CHAFFA, E. SANYA et al. studied the influence of factors relating to building envelope elements on building energy consumption [21]. The analysis of the energy efficiency of building was carried out in two stages: the first stage concerns the influence of envelope elements of the energy consumption of building while the second examines the influence of equipment operating measures, in particular for air conditioning, on their energy consumption.

Their study revealed that the consumption of air conditioned building is reduced the more the buildings are oriented, the bay windows are small and protected against direct sunlight: Opening ratio/Weak wall / Awning Depth/Window Height Ratio (RLL) and Ridge Width/Window Width Ratio (RLL) large and glazing that is not very permeable to solar radiation (low solar factor Fs). This energy consumption has been reduced by around 38 to $45 \%$ by applying appropriate measures to operate air conditioning equipment in a fleet of 110 buildings that consume the most energy in Ivory Coast.

In the following section, a focus is made on the environmental impact of the artificial cooling of the building studied.

Table 8. TEWI evaluation for the different configurations (Living).

\begin{tabular}{|c|c|c|c|c|}
\hline & Breeze Block (reference) & Cement + rice husks & Cement roast wood fibres & Cement + bar soil \\
\hline Cooling capacity (kW) & 2.884 & 2.314 & 2.570 & 3.789 \\
\hline $\mathrm{Ea}(\mathrm{kWh} / \mathrm{an})$ & 1922.67 & 1542.67 & 1713.33 & 2526 \\
\hline TEWI $\left(\mathrm{kg}\right.$ eq $\left.\mathrm{CO}_{2}\right)$ & 20991 & 17525.40 & 19081.81 & 26493.37 \\
\hline$\% \mathrm{CO}_{2}$ eq gain (compared to the reference) & 0 & -17 & -9 & +26.21 \\
\hline
\end{tabular}

Table 9. TEWI evaluation for the different configurations (Room).

\begin{tabular}{|c|c|c|c|c|}
\hline & Breeze Block (reference) & Cement + rice husks & Cement roast wood fibres & Cement + bar soil \\
\hline Cooling capacity (kW) & 3.703 & 2.538 & 2.711 & 3.536 \\
\hline $\mathrm{Ea}(\mathrm{kWh} / \mathrm{an})$ & 2468.67 & 1692 & 1807.33 & 2357.33 \\
\hline TEWI ( $\mathrm{kg}$ eq $\left.\mathrm{CO}_{2}\right)$ & 25970.52 & 18887.30 & 19939 & 24955 \\
\hline$\% \mathrm{CO}_{2}$ eq gain (compared to the reference) & 0 & -27.27 & -23.22 & -4 \\
\hline
\end{tabular}

Tables 8 and 9 present the TEWI assessment for the different configurations for the living room and bedroom. The "cement+rice husks" and "cement+ roast wood fibres" configurations have a low environmental impact compared to the reference configuration of "breeze block+cement" and "cement+bar soil". The "cement+rice husks" and "cement+roast wood fibres" configurations respectively show a $17 \%$ and $9 \%$ reduction in $\mathrm{CO}_{2}$ emissions for the living room and $27 \%$ and $23 \%$ respectively for the bedroom, compared to the reference configuration.

\section{Conclusion}

The present work is a contribution to the improvement of energy efficiency in buildings by analysing the possibilities of using local building materials to reduce energy consumption related to air conditioning. The impact of thermal insulation on indoor air temperature and cooling requirements was investigated using four different materials used in building construction in Benin. For this purpose, we used the composites "cement+roast wood fibre", "cement+rice husk", "breeze 
block+cement (reference)" and the composite "cement+bar soil". From this study, it appears that the best material to fight effectively against external thermal variations and allowing better energy savings in the case of air conditioning is the "cement+rice husks" composite. This is followed by the "cement+roast wood fibre" composite. Next is the "cement+bar soil" composite, which is better than the "agglomerate". They reduce the cooling requirement for air-conditioning in the living room by $20 \%$ and $11 \%$ respectively, and by $32 \%$ and $27 \%$ respectively in the bedroom, compared to the reference building made of "agglomerate" for a wall thickness e $=0.15 \mathrm{~m}$. They therefore have a better environmental performance. The study showed that for the "cement + bar soil" composite, the cooling requirement increased by $31 \%$ for the living room and decreased by $5 \%$ for the bedroom compared to the "chipboard" reference building. The environmental impact by estimating the TEWI of the different materials was also assessed. The "cement+rice husks" and "cement+ roast wood fibre" configurations have a low environmental impact compared to "chipboard" and "cement+bar soil". The "cement+rice husks" and "cement+ roast wood fibre" configurations respectively show a $17 \%$ and $9 \%$ reduction in $\mathrm{CO} 2$ emissions for the living room and $27 \%$ and $23 \%$ respectively for the bedroom, compared to the "chipboard" reference configuration. It is therefore urgent to review the current construction habits strongly marked by the use of "agglomerates", as this is very detrimental to comfort in view of the characteristic comfort values obtained with other materials such as "cement + rice husks" and "cement + roast wood fibres" composites.

\section{Nomenclature}

$\mathrm{E}_{\mathrm{a}}$ : Annual energy consumption ( $\mathrm{kWh} /$ year)

L: Annual quantity of refrigerant lost through leakage [kg/year]

$\mathrm{m}$ : Quantity of refrigerant in the heat pump at installation (kg/year)

$\mathrm{n}$ : Lifetime of the installation (years)

$\mathrm{GWP}_{100}$ : Global warming potential of the refrigerant

$\left(\mathrm{kg}_{\text {equi } \mathrm{CO} 2}\right)$

$\dot{Q}_{\text {inf: }}$ Infiltration gain of outdoor air flow (W)

$\dot{Q}_{\text {vent }}:$ Gains by ventilation of the HVAC system (W)

$\dot{Q}_{\text {surf: }}$ Convective heat flux from any indoor surface (W)

$\dot{Q}_{\text {gain }}$ : Internal convective inputs (lighting, occupants, appliances) (W)

$\dot{Q}_{\text {cplg: }}$ Gains due to convective airflow from a zone (W)

$\dot{Q}_{T}$ : Overall energy balance (W)

$\mathrm{S}_{s, i}$ : Radiation heat flux absorbed at the indoor surface (solar and radiative gains) (W)

$\mathrm{S}_{s, o}$ : Radiation heat flux absorbed at the outdoor surface (solar gains)

$\mathrm{T}_{f}$ : Fluid temperature $(\mathrm{W})$

$\mathrm{T}_{i}$ : Indoor temperature $\left({ }^{\circ} \mathrm{C}\right)$

$\mathrm{T}_{\text {max }}$ : Maximum temperature $\left({ }^{\circ} \mathrm{C}\right)$

$\mathrm{T}_{\text {min }}$ : Minimum temperature $\left({ }^{\circ} \mathrm{C}\right)$

$\mathrm{T}_{p}:$ Wall temperature $\left({ }^{\circ} \mathrm{C}\right)$

$\mathrm{T}_{s, I}$ : Temperature of the interior surface $\left({ }^{\circ} \mathrm{C}\right)$
$\mathrm{T}_{\text {vent }, i}$ : Air ventilation temperature $\left({ }^{\circ} \mathrm{C}\right)$

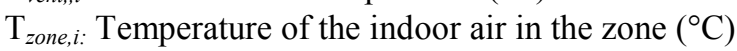

$\mathrm{T}_{s, o}$ : Outdoor surface temperature $\left({ }^{\circ} \mathrm{C}\right)$

$\mathrm{T}_{\text {ext }}$ : Outdoor air temperature $\left({ }^{\circ} \mathrm{C}\right)$

$\dot{V}$ : Air volume flow rate $\left(\mathrm{m}^{3} / \mathrm{s}\right)$

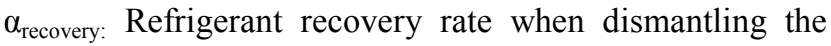
heat pump (-)

$\beta$ : $\mathrm{CO}_{2}$ emission rate for the production of $1 \mathrm{kWh}$ energy ( $\mathrm{kg} \mathrm{CO} / \mathrm{kWh})$

$\mathrm{C}_{\mathrm{a}}$ : Heat capacity of air

$\mathrm{h}_{\mathrm{c}}$ : Convective heat exchange coefficient $\left(\mathrm{W} \cdot \mathrm{m}^{-2} \cdot \mathrm{K}^{-1}\right)$ pa: Density of air $\left(\mathrm{kg} . \mathrm{m}^{-3}\right)$

\section{References}

[1] Document, 'Version complète PAG Bénin révélé 2016-2021', Projet phare du secteur de l'énergie, page 59.

[2] Revue, 'Le livre blanc de l'efficacité énergétique', Schneider Electric, 2011, 32p.

[3] Rapport, 'Policy Pathway: Modernising Building Energy Codes', AIE-UNDP, 2013, 74p.

[4] Rapport, 'Système d'information énergétique du Bénin', Direction Générale de l'Energie, 2010, 142p.

[5] H. Necib, R. Belakroum et K. Belakroum, 'Amélioration de l'isolation thermique des habitats dans les régions chaudes et arides', Third International Conference on Energy, Materials, AppliedEnergetics and Pollution, 2016.

[6] NefissaBelkacem, 'Contribution à l'évaluation des performances énergétiques et environnementales d'un habitat individuel bioclimatique: cas de la maison pilote de Souidania, Alger, Algérie', Thèse de Doctorat, Université HassibaBenbouali de Chlef, pp. 88, 2017.

[7] Thomas Marchal, 'Modélisation en régime dynamique d'une maison basse énergie Etude de cas Maison Politehnica', Mémoire de Master, Université de Lorraine, Faculté des Sciences et Technologie de Nancy, 2014.

[8] Jedidi et al, 'Etude de l'efficacité énergétique d'un bâtiment en Tunisie', $1^{\mathrm{er}}$ Colloque International des Energies Nouvelles et Renouvelables- Innovation et Progrès Scientifiques CIENRIPS, 2018.

[9] Oscar Godonou, 'Etude comparative de la capacité de rétention thermique de quelques matériaux locaux de construction au Bénin', Mémoire de Master Génie Mécanique et Energétique, Université d'Abomey-Calavi, Ecole Polytechnique d'Abomey-Calavi, 118p, 2015.

[10] Henri Hounkpatin, Victorin Chegnimonhan, Guy Clarence Sèmassou, Basile Kounouhewa, Emile Sanya and Antoine Vianou, 2018 'Study of the impact of thermal inputs by roofs on the hygrothermal comfort of habitats in tropical environment', International Journal of Current Research, 10, (08), 72323-72336.

[11] Dirk Nathaniels, 'Simulation thermique dynamique de l'influence des apports thermiques par la toiture sur le confort dans un bâtiment résidentiel au Sud du Bénin' Mémoire de Master Energies Renouvelables et Systèmes Energétiques, Université d'Abomey-Calavi, 2018. 
[12] Document, 'TRNSYS Version 17, User Manual, Multizone Building modeling with Type56 and TRNBuild,', Solar Energy Laboratory, University of Wisconsin, Madison, pp. 147-148, 2014.

[13] Moreno, B., Del Ama Gonzalo, F., Fernandiz, J. A., Lauret, B. Hernandez, JA. A building energy simulation methodology to validate energy balance and comfort in zero energy buildings. Journal of Energy Systems 2019, 3 (4), 168-182, DOI: $10.30521 /$ jes. 623285 .

[14] Aymeric Novel. Développement d'une méthode de méta modélisation des consommations énergétiques des bâtiments en fonction des facteurs d'usages et d'exploitation pour la garantie de résultat énergétique. Génie civil. Université de La Rochelle, 2019.

[15] Ahcène Djemaa. Modélisation bottom-up, un outil d'aide à la decision long terme pour les mesures politiques en matière d'énergie et d'environnement: le modèle TIMES appliqué aux industries grandes consommatrices d'énergie. Sciences de l'Homme et Société. Ecole Nationale Supérieure des Mines de Paris, 2009.

[16] C. K. Cheung, R. J. Fuller and M. B. Luther, 'Energy Efficient Envelope Design for High Rise Apartments', Energy and Building, Vol. 37, №1, pp. 37-48, 2005.
[17] N. Safer, 'Modélisation des Façades de Type Double-Peau Equipées de Protections Solaires: Approches Multi-Echelles', Thèse de Doctorat, INSA de Lyon, Centre de Thermique de Lyon, 2006.

[18] Madi Kaboré, 'Enjeux de la simulation pour l'étude des performances énergétiques des bâtiments en Afrique subsaharienne', Thèse de Doctorat, Université Grenoble Alpes, pp. 70, 2015.

[19] K. DOKO, 'Formulation et étude comparative des proprietés physiques, mécaniques et thermiques des composites à matrice cimentaire renforcée par des biomasses végétales: cas des fibres de Aethiopum Borassus Mart et des balles de riz', Thèse de Doctorat de l'Université d'Abomey-Calavi, 2013.

[20] G. CHAFFA, C. AWANTO, L. A. FAGBEMI., 'Amélioration des conditions d'ambiance intérieure en zone tropicale sèche: cas des habitations dans la région septentrionale du Bénin', Communication 5ème Colloque des Sciences, Cultures et Technologies de l'Université d'AbomeyCalavi, 28 Septembre au 03 Octobre, 2015.

[21] G. CHAFFA, E. SANYA, M. SAKO, Y. N'GUESSAN., 'Analyse de l'efficacité énergétique des bâtiments climatisés en région chaude', LEMA, LFT. 